\title{
DIGLOSIA
}

\section{HUBUNGAN MINAT BACA DENGAN KEMAMPUAN MENULIS TEKS EKPOSISI SISWA KELAS XI SMK NEGERI 9 SAMARINDA}

\author{
Kristina Septhin ${ }^{1, *}$, Widyatmike Gede Mulawarman ${ }^{2}$, Bibit Suhatmady ${ }^{3}$ \\ ${ }^{1}$ Magister Pendidikan Bahasa dan Sastra Indonesia, FKIP Universitas Mulawarman \\ ${ }^{2,3}$ Fakultas Keguruan dan Ilmu Pendidikan, Universitas Mulawarman \\ *Pos-el korespondensi: tinakristin7@gmail.com
}

\begin{abstract}
This study aims to find out the relationship between reading interest and the ability to write exposition text of class XI students of SMK Negeri 9 Samarinda. This research is a quantitative research with Product Moment correlation analysis. The population in this study were class XI students of SMK Negeri 9, which amounted to 261 students. The research sample amounted to 166 students. The sampling technique used cluster random sampling. There were three variables in this study, two independent variables and one dependent variable. Questionnaires and tests were used to collect the data. Based on the analysis of the data it can be concluded it seems that there is a positive and significant relationship between reading interest in the ability to write exposition texts in class XI students of SMK Negeri 9 Samarinda which is indicated by a correlation coefficient $\left(\mathrm{r}_{\mathrm{x} 1 \mathrm{y}}\right)$ of 0.305 and a calculated value greater than $r_{\text {table }}$ with $\mathrm{N}=166$ at the error rate of $5 \%(0.305>$ 0.159) which means that the higher the reading interest of students, the higher the ability to write exposition text.
\end{abstract}

Keywords: reading interest, exposition text, writing ability

\begin{abstract}
ABSTRAK
Penelitian ini bertujuan untuk mengetahui hubungan minat baca dengan kemampuan menulis teks eksposisi siswa kelas XI SMK Negeri 9 Samarinda. Penelitian ini merupakan penelitian kuantitatif dengan analisis korelasi Product Moment. Populasi dalam penelitian ini adalah siswa kelas XI SMK Negeri 9 yang berjumlah 261 siswa. Sampel penelitian berjumlah 166 siswa. Teknik pengambilan sampel menggunakan sampel cluster random sampling. Ada tiga variabel dalam penelitian ini yaitu dua variabel bebas dan satu veriabel terikat. Teknik pengumpulan data menggunakan kuesioner dan tes. Pengumpulan data menggunakan metode Kuesioner dan tes. Berdasarkan analisis data dapat disimpulakan terdapat hubungan yang positif dan signifikan antara minat baca terhadap kemampuan menulis teks eksposisi pada siswa kelas XI SMK Negeri 9 Samarinda yang ditunjukan dengan koefisien korelasi $\left(\mathrm{r}_{\mathrm{x} 1 \mathrm{y}}\right)$ sebesar 0,305 dan nilai $\mathrm{r}_{\text {hitung }}$ lebih besar dari $\mathrm{r}_{\text {tabel }}$ dengan $\mathrm{N}=$ 166 pada taraf kesalahan $5 \%(0,305>0,159)$ yang berarti bahwa semakin tinggi minat baca siswa maka akan semakin tinggi pula kemampuan menulis teks eksposisi.
\end{abstract}

Kata kunci: minat baca, teks ekposisi, kemampuan menulis 


\section{A. PENDAHULUAN}

Membaca merupakan satu dari empat kemampuan bahasa pokok dan merupakan satu bagian atau komponen dari komunikasi tulisan. Adapun kemampuan bahasa pokok dalam kurikulum di sekolah mencakup empatsegi, yaitu: (a) kemampuan menyimak/mendengarkan (listening skills); (b) kemampuan berbicara (speaking skills); (c) kemampuan membaca (reading skills); dan (d) kemampuan menulis (writing skills). Keempat kemampuan berbahasa tersebut memiliki keterkaitan yang sangat erat satu sama lain dan saling berhubungan.

Minat merupakan salah satu faktor yang cukup penting yang mempengaruhi kemampuan membaca. Minat adalah perpaduan antara keinginan dan kemauan yang dapat berkembang jika ada motivasi sebagaimana dikemukakan Tampubolon (dalam Iskandarwassid, 2009:113). Kegiatan yang diminati akan diperhatikan terus menerus dan bila dilakukan akan disertai rasa senang. Minat dapat menimbulkan sikap yang merupakan suatu kesiapan berbuat bila ada stimulus khusus sesuai dengan keadaan tersebut.

Kemampuan berbahasa pada umumnya secara berturut-turut dimulai dari keterampilan menyimak, berbicara, membaca dan menulis. Dibandingkan dengan tiga kemampuan bahasa lain, kemampuan menulis merupakan kemampuan berbahasa yang paling sulit dikuasai. Hal tersebut disebabkan kemampuan menulis menghendaki penguasaan berbagai unsur kebahasaan dan unsur diluar bahasa itu sendiri yang akan menjadi tulisan.

Kegiatan menulis memerlukan adanya kompleksitas kegiatan untuk menyusun karangan secara baik yang meliputi: keterampilan gramatikal, penuangan isi, keterampilan stilistika, keterampilan mekanis, dan keterampilan memutuskan Heaton (dalam Slamet,
2007:142). Salah satu dari beberapa kemampuan menulis yaitu kemampuan menulis teks eksposisi. Kemampuan menulis teks ekposisi merupakan salah satu keterampilan menulis yang terdapat dalam silabus mata pelajaran Bahasa dan Sastra Indonesia untuk SMK kelas XI.

Mengingat bahwa dalam penentuan kelulusan siswa dari satuan pendidikan diperlukan standar kompetensi kelulusan yang digunakan sebagai pedoman penilaian, maka kompetensi lulusan untuk mata pelajaran bahasa menekankan pada kemampuan membaca dan menulis. Hal tersebut sesuai dengan Peraturan Pemerintah Republik Indonesia Nomor 19 Tahun 2005 tentang Standar Nasional Pendidikan (Pasal 25 Ayat 3) yang menyatakan bahwa kompetensi lulusan untuk mata pelajaran bahasa menekankan pada kemampuan membaca dan menulis yang sesuai dengan jenjang pendidikan.

Tujuan penelitian ini adalah untuk mengetahui hubungan antara minat baca, penguasaan kebahasaan dan kemampuan menulis teks eksposisi siswa kelas XI SMK Negeri 9 Samarinda. Secara khusus tujuan penelitian ini adalah untuk mengetahui hubungan antara minat baca dengan kemampuan menulis teks eksposisi siswa kelasXI SMK Negeri 9 Samarinda.

\section{B. LANDASAN TEORI}

\section{Definisi Membaca}

Membaca merupakan hal yang penting dalam kehidupan masyarakat yang semakin kompleks. Setiap aspek kehidupan melibatkan kegitan membaca. Menurut Kamus Besar Bahasa Indonesia, membaca berasal dari kata baca yaitu melihat serta memahami isi dari apa yang tertulis (dengan melisankan atau hanya dalam hati). Sementara menurut Tarigan (2008:7), membaca adalah suatu proses yang dilakukan serta dipergunakan oleh pembaca untuk memperoleh pesan yang hendak disampaikan oleh penulis melalui 
media kata-kata atau bahasa tulis. Dalam dunia pendidikan aktivitas membaca merpakan suatu hal yang tidak bisa ditawar, sebagain besar pemerolehan ilmu dilakukan siswa bahkan mahasiswa melalui aktivitas membaca. Dengan demikian membaca memberikan pengaruh yang posisitif bagi pembaca, kemampuan dan kemauan membaca sangat mempengaruhi keluasan pandangan tentang berbagai masalah.

\section{Definisi Minat Baca}

Pada era modern ini budaya membaca kurang diminati karena berbagai macam alasan. Oleh karena itu, minat baca yang rendah inilah yang membuat sumber daya manusia yang rendah sehingga membuat negara ini semakin terpuruk sangat memprihatinkan. Rendahnya minat baca masyarakat Indonesia makin menyebabkan kualitas dan mutu pendidikan di Indonesia juga hanya di tempat dan cenderung mundur.

Minat dalam KBBI berarti kecendrungan hati yang tinggi terhadap sesuatu gairah atau keinginana. Sama halnya dengan membaca ketika seseorang tidak memiliki minat dalam hatinya untuk membaca maka tidak akan orang lakukan, karena minat bacapun harus timbul dari dalam hati dengan dorongan yang sangat kuat. Apabila seseorang tidak memiliki minat baca maka tidak akan menyenangi suatu bacaan yang dilihat atau hanya sekedar dipandang. Ginting (dalam Meliyawati, 2016:31) mengemukakan minat baca adalah bentuk-bentuk prilaku yang terarah guna melakukan kegiatan membaca sebagai tingkat kesenangan yang kuat dalam melakukan kegiatan membaca karena menyenangkan dan memberikan nilai.

Minat baca adalah salah satu faktor yang memiliki peranan penting dalam kegiatan membaca, di dalam masyarakat kita khususnya minat baca cenderung kecil jika dibandingkan dengan peran minat-minat lain, seperti minat pada bidang ekstrakulikuler disekolah formal khususnya. Padahal jika seseorang menyadari minat baca lebih penting maka seharusnya minat tersebut dibiasakan sejak dini agar terbiasa serta kegiatan tersebut benar-benar timbul dari dalam hati seseorang. Minat baca ditunjukkan dengan keinginan yang kuat untuk melakukan kegiatan membaca. Hal ini dikarenakan minat membaca merupakan salah satu faktor penting yang akan membantu anak untuk segera siap membaca.

Minat adalah kecenderungan yang tetap untuk memperhatikan dan mengenal beberapa kegiatan. Apabila seseorang mempunyai minat yang tinggi terhadap sesuatu hal maka akan terus berusaha untuk melakukan sehingga apa yang diinginkan dapat tercapai sesuai keinginannya. Slameto (dalam Marbun, 2018:62) mengemukakan bahwa minat adalah kecenderungan yang tetap untuk memperhatikan dan mengenang beberapa kegiatan, kegiatan yang dimiliki seseorang, diperhatikan terus disertai dengan rasa sayang. Minat besar pengaruhnya terhadap belajar atau kegiatan, bahkan pelajaran yang menarik minat siswa lebih mudah dipelajari dan disimpan karena minat menambah kegiatan belajar. Untuk menambah minat seorang siswa di dalam menerima pelajaran di sekolah, siswa diharapkan dapat mengembangkan minta untuk melakukannya sendiri. Berdasarkan beberapa pendapat ahli mengenai minat membaca, maka aspek-aspek minat baca meliputi: (a) motivasi, (b) kebutuhan, (c) kesenangan keinginan mencari bahan bacaan, (d) perhatian, dan (e) keinginan.

\section{Definisi Menulis}

Dalam kehidupan moderen ini jelas bahwa keterampilan menulis sangat dibutuhkan, tidaklah berlebihan bila kita katakan bahwa keterampilan menulis merupakan suatu ciri dari orang yang terpelajar. Menulis merupakan salah satu 
dari empat keterampilan berbahasa yang mendasar (berbicara, menyimak, menulis dan membaca). Menulis tidak dapat dilepaskan dari kegiatan berbahasa lainnya. Apa yang diperoleh melalui menyimak, membaca, dan berbicara akan memberikan masukan berharga untuk kegiatan menulis. Keterampilan menulis dikuasai seseorang sesudah menguasai keterampilan berbahasa yang lain. Dengan demikian keterampilan menulis salah satu dari keterampilan berbahasa yang di kuasai sesudah menguasai keterampilan menyimak, berbicara dan membaca.

McCrimmon (dalam Saddhono 2012:96) menyatakan bahwa menulis merupakan kegiatan menggali pikiran dan perasaan mengenai suatu subjek, memilih hal-hal yang akan ditulis, menentukan cara menuliskannya sehingga pembaca dapat memahaminya dengan mudah dan jelas. Senada dengan pendapat McCrimmon, Lawrence (dalam Saddhono, 2012:96) mengatakan bahwa menulis adalah mengkomunikasikan apa dan bagaimana pikiran penulis. Pada dasarnya menulis bukan hanya melahirkan pikiran atau perasaan saja tetapi, melainkan juga pengungkapan ide, pengetahuan, ilmu dan pengalaman hidup seseorang dalam bahasa tulis. Oleh karena itu menulis bukanlah merupakan kegiatan yang sederhana dan tidak perlu dipelajari tetapi dikuasai. Menulis disamping sebagai suatu proses, menulis juga merupakan suatu kegiatan yang kompleks.

\section{Teks Eksposisi}

Kata eksposisi berasal dari bahasa inggris exposition yang berarti "membuka" atau "memulai". Eksposisi itu sendiri merupakan karangan yang bertujuan utama memberitahu, mengupas, menguraikan atau menerangkan sesuatu. Ekposisi atau ekspositoris adalah tulisan yang bersifat faktual. Eksposisi adalah tulisan yang memberikan informasi mengenai mengapa dan bagaimana menjelaskan sebuah proses atau menjelaskan sebuah konsep. Tulisan ekposisi memberitahukan kepada pembaca bagaimana dan mengapa sehingga sesuatu terjadi. Secara definisi tulisan atau karangan eksposisi fokus pada dua pertanyaan yaitu why dan how, atau mengapa dan bagaimana.

Eksposisi (paparan) adalah salah satu bentuk tulisan atau retorika yang berusaha untuk menerangkan dan menguraikan suatu pokok pikiran, yang dapat memperluas pandangan atau pengetahuan seseorang yang membaca uraian tersebut (Keraf, 1981:3). Menurut Hasani (2005:30), eksposisi merupakan bentuk tulisan yang sering digunakan dalam menyampaikan uraian ilmiah dan tidak berusaha mempengaruhi pendapat pembaca.

\section{Teknik Penulisan Teks Eksposisi}

Dalam isi penulis mengekspos segala hal yang berhubungan dengan topik, diantaranya adalah (1) pengertian, (2) mengapa dan (3) bagaimana. Pada bagian terkhir, yaitu konklusi atau kesimpulan, penulis membuat semacam sintesis mengenai hal-hal yang subtansial dalam pemaparan topik. Sebuah teks eksposisi biasanya diwarnai oleh sifat topik yang digarap dan teknik penyajian yang digunakan. Keterampilan penulis memadukan kedua unsur itu dengan jalinan bahasa yang baik dan lancar akan menandai kualitas sebuah eksposisi. Lebih lanjut dikatakan, bahwa teks eksposisi mengandung tiga bagian utama, yaitu (1) pendahuluan, (2) tubuh eksposisi, dan (3) kesimpulan.

\section{Hubungan Minat Baca dengan Kemampuan Menulis Teks Eksposisi}

Kegiatan membaca sangat dibutuhkan dalam berbagai segi kehidupan. Dengan membaca siswa akan memiliki pola pikir yang lebih baik dan 
pola penalaran yang lebih baik. Dengan membaca seseorang khususnya siswa akan memiliki pengetahuan yang luas. Pengetahuan atau pengalaman siswa dapat diperoleh dengan cara membaca. Tujuan utama dalam membaca adalah untuk mencari dan memperoleh informasi, isi, dan memahami makna bacaan. Banyaknya bacaan yang dibaca tergantung oleh minat baca seseorang, maka dari itu minat baca berpengaruh dalam kemampuan menulis teks eksposisi.

Adanya minat baca akan memberikan dorongan yang kuat untuk membaca. Suatu aktivitas tidak akan berhasil mencapai tujuannya tanpa didasari minat terhadapnya. Apabila memiliki minat baca yang tinggi maka frekuensi membaca juga tinggi yang akhirnya ilmu pengetahuan dan pengalamannya bertambah. Hal itu akan berpengaruh pula dalam kemampuan menulis teks eksposisi. Membaca merupakan kegiatan pendukung untuk melakukan kegiatan menulis eksposisi. Siswa yang memiliki motivasi membaca makin tinggi, diduga eksposisi yang dihasilkan semakin baik daripada siswa yang memiliki motivasi membacanya rendah. Pengetahuan atau pengalaman siswa dapat diperoleh dengan cara membaca. Tujuan utama dalam membaca adalah untuk mencari dan memperoleh informasi, isi, dan memahami makna bacaan. Banyaknya bacaan yang dibaca tergantung oleh minat baca seseorang, maka dari itu minat baca berpengaruh dalam kemampuan menulis teks eksposisi.

\section{METODE PENELITIAN}

Metode yang digunakan pada penelitian ini adalah penelitian kuantitatif. Metode penelitian kuantitatif diartikan sebagai metode penelitian yang berdasarkan pada filsafat positivisme, digunakan untuk meneliti pada populasi dan sampel tertentu, teknik pengambilan sampel pada umumnya penelitian, analisis data bersifat kuantitatif/statistik dengan tujuan untuk menguji hipotesis yang telah ditetapkan. Desain penelitian ini menggunakan penelitian korelasi atau penelitian korelasional. Penelitian ini berusaha untuk menemukan ada tidaknya hubungan antara minat baca dengan kemampuan menulis teks eksposisi. Penelitian ini menguji hubungan antara variabel bebas dengan variabel terikat. Penelitian ini dilaksanakan di SMK Negeri 9 Samarinda yang berjumlah 261 siswa dan sampel penlitian berjumlah 166 siswa.

Instrument yang digunakan dalam penelitian ini adalah berupa kuesioner dan tes dengan daftar pertanyaan sebagai alat mengetahui data responden. Bentuk butir-butir kuesioner disusun dalam pertanyaan yang akan dijawab oleh responden dengan pilihan jawaban sesuai dengan kondisi masing-masing siswa. Instrumen ini antara lain untuk pengukuran minat baca (X) dengan kuesioner skala likert. Sedangkan variabel terikatnya adalah kemampuan menulis teks eksposisi (Y) yang diukur dengan tes menulis teks ekposisi. Selanjutnya instrumen yang disusun tersebut terlebih dahulu diujicobakan untuk dihitung validitas dan reliabilitannya. Validitas instrumen ini merupakan validitas content atau validitas isi. Hal ini dilakukan dengan tujuan untuk menjamin kualitas instrumen tersebut. Pengumpulan data dalam penelitian ini dijelaskan secara rinci masing-masing variabel yang digunakan dalam penelitian ini.Analisis data dilakukan dengan tujuan untuk menguji hipotesis dalam rangka menarik kesimpulan. Adapun metode analisis yang digunakan dalam penelitian ini terdiri dari dua bagian, yaitu analisis data deskriptif dan inferensial.

Analisis data deskriptif dilakukan dengan menyajikan data melalui tabel distribusi frekuensi yang umumnya menggunakan histogram, kemudian 
dilanjutkan dengan perhitungan nilai sentral untuk melihat sebaran data dengan menghitung modus, median, dan mean. Selanjutnya dapat dilihat variansi data dengan menggunakan range, varians, standar deviasi, dan koefisien variasi (Taniredja dan Mustafidah, 2012:61).

Analisis data inferensial adalah teknik analisis statistik yang digunakan untuk menganalisis data sampel dan hasilnya diberlakukan untuk populasi yang jelas, teknik pengambilan sampel dari populasi itu dilakukan secara random (Sugiyono, 2014:209). Analisis ini dilakukan dengan terlebih dahulu uji persyaratan sebagai syarat untuk uji hipotesis.

\section{HASIL DAN PEMBAHASAN}

\section{Minat baca}

Data variabel minat baca siswa kelas XI SMK Negeri 9 Samarinda diukur dengan menggunakan angket yang terdiri dari 29 butir pernyataan, dengan skala yang digunakan adalah skalalikert dengan empat pilihan. Skor yang mungkin diperoleh memiliki rentang 29-116. Berdasarkan data variabel minat baca (X) yang diolah menggunakan program SPSS versi 20, maka diperoleh nilai maksimal 105 dan nilai minimal 60 sehingga range 45. selain itu didapatkan nilai mean 84,5 , median 85 , modus 95, dan standar deviasi 10,2 (perhitungan lengkap dapat dilihat pada lampiran). Sedangkan menghitung jumlah kelas interval menggunakan rumus sebagai berikut.

$$
\begin{aligned}
& K=1+3,3 \log n \\
& K=1+3,3 \log 166 \\
& K=8,3 \text { dibulatkan menjadi } 8 .
\end{aligned}
$$

Sedangkan rentan data hitung dengan menggunakan rumus nilai maksimal-nilai minimal, sehingga diperoleh data sebesar 105-60 = 45 . Panjang kelas menggunakan rumus

$$
\frac{\text { rentan data }}{\text { kelas interval }}
$$

sehingga diperoleh panjang kelas, yaitu 5,6 dibulatkan menjadi 6. Distribusi

\begin{tabular}{|c|c|c|c|}
\hline \multicolumn{2}{|c|}{ Skor Minat Baca } & \multirow{2}{*}{ Frekuensi (f) } & \multirow{2}{*}{ Persentase $(\%)$} \\
\hline Interval & Kategori & & \\
\hline$>95$ & Tinggi & 32 & 19,2 \\
\hline $75 \leq \mathrm{X} \leq 95$ & Sedang & 112 & 67,4 \\
\hline$<75$ & Rendah & 22 & 13,2 \\
\hline \multicolumn{2}{|c|}{ Jumlah } & 166 & 100 \\
\hline
\end{tabular}
frekuensi skor dapat dilihat pada tabel berikut.

Tabel 1. Distribusi Frekuensi Skor 
Tabel 2. Distribusi Frekuensi Skor Variabel Minat Baca

\begin{tabular}{cccc}
\hline No. & $\begin{array}{c}\text { Interval } \\
\text { Kelas }\end{array}$ & \multicolumn{3}{c}{ Preksentase } \\
$(\%)$
\end{tabular}

Dari hasil pengumpulan data perolehan skor minat baca siswa kelas XI SMK Negeri 9 Samarinda adalah sebagai berikut. Skor tertinggi pada angket minat baca adalah 105 dan skor terendah adalah 60 dengan range 45 serta rata-rata 84,5 dan standar deviasi sebesar 10,2. Dari 166 siswa yang diteliti, sebanyak 32 siswa atau $19,2 \%$ berada pada kategori tinggi, sebanyak 112 siswa atau $67,4 \%$ berada pada kategorisedang, dan 22 siswa atau $13,2 \%$ berada pada kategori rendah. Sehingga dapat disimpulkan bahwa frekuensi terbesar perolehan skor angket minat baca siswa berada pada kategori sedang dengan persentase 67,4\%. Berdasarkan tabel tersebut dapat digambarkan pie chart sebagai berikut.

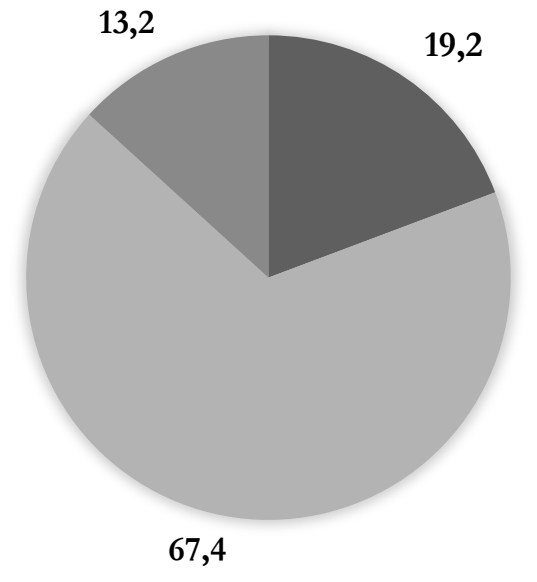

Gambar 1.

Distribusi Kecenderungan Variabel Minat Baca

\section{Kemampuan Menulis Teks Eksposisi}

Data variabel kemampuan menulis teks ekposisisiswa kelas XI SMK Negeri 9 Samarindadiukur dengan menggunakan tes menulis teks ekposisi. Skor yang mungkin diperoleh memiliki rentang 0 100. Berdasarkan data variabel penguasaan kebahasaan (X2) yang diolah menggunakan program SPSS versi 20, 
maka diperoleh nilai maksimal 87 dan nilai minimal 59 sehingga range 28 . selain itu didapatkan nilai mean 75,1 , median 75 , modus 75, dan standar deviasi 5,53 (perhitungan lengkap dapat dilihat pada lampiran). Sedangkan menghitung jumlah kelas interval menggunakan rumus sebagai berikut:

$$
\begin{aligned}
& K=1+3,3 \log n \\
& K=1+3,3 \log 166 \\
& K=8,3 \text { dibulatkan menjadi } 8
\end{aligned}
$$

Sedangkan rentan data hitung dengan menggunakan rumus nilai maksimal-nilai minimal, sehingga diperoleh data sebesar $87-59=28$.

Panjang kelas menggunakan rumus:

$$
\frac{\text { rentan data }}{\text { kelas interval }}
$$

\begin{tabular}{|c|c|c|c|}
\hline No. & Interval Kelas & Frekuensi & Persentase $(\%)$ \\
\hline 1. & $59-62$ & 2 & 1,2 \\
\hline 2. & $63-66$ & 11 & 6,62 \\
\hline 3. & $67-70$ & 25 & 15 \\
\hline 4. & 71-74 & 28 & 16,8 \\
\hline 5. & 75-78 & 51 & 30,7 \\
\hline 6. & 79-82 & 34 & 20,4 \\
\hline 7. & $83-86$ & 14 & 8,43 \\
\hline 8 & 87 & 1 & 0,6 \\
\hline \multicolumn{2}{|r|}{ Jumlah } & 166 & 100 \\
\hline
\end{tabular}

sehingga diperoleh panjang kelas yaitu 3,5 dibulatkan menjadi 4. Distribusi frekuensi skor dapat dilihat pada tabel berikut.

\section{Tabel 3. Distribusi Frekuensi Skor Variabel Menulis Teks Eksposisi}

Dari hasil pengumpulan data Perolehan skor tes kemampuan menulis teks

\begin{tabular}{|c|c|c|c|}
\hline \multicolumn{2}{|c|}{ Skor Kemampuan Menulis Teks Ekposisi } & \multirow{2}{*}{$\begin{array}{l}\text { Frekuensi } \\
\text { (f) }\end{array}$} & \multirow{2}{*}{$\begin{array}{c}\text { Persentase } \\
(\%)\end{array}$} \\
\hline Interval & Kategori & & \\
\hline$>81$ & Tinggi & 21 & 12,6 \\
\hline $70 \leq X \leq 81$ & Sedang & 122 & 73,4 \\
\hline$<70$ & Rendah & 23 & 13,8 \\
\hline \multicolumn{2}{|c|}{ Jumlah } & 166 & 100 \\
\hline
\end{tabular}
ekposisi siswa kelas XI SMK Negeri 9
Samarinda dapat dilihat pada tabel berikut ini.

Tabel 4. KlasifikasiKemampuan Menulis Teks Ekposisi

Berdasarkan tabel 4 di atas terlihat bahwa skor tertinggi yang diperoleh untuk tes kemampuan menulis teks eksposisi adalah 87 dan skor terendah yang diperoleh adalah59dengan range 28serta rata-rata 75,1 dan standar deviasi sebesar 5,5. Dari166 siswa yang diteliti, sebanyak 21 siswa atau $12,6 \%$ berada pada kategori tinggi, sebanyak 122 siswa atau $73,4 \%$ berada pada kategorisedang, dan sebanyak 23siswa atau 13,8\% berada pada kategori rendah. Sehingga dapat disimpulkan bahwa frekuensi terbesar perolehan skor teskemampuan 
menulis teks ekposisi sedang dengan persentase $73,4 \%$. Berdasarkan tabel tersebut dapat digambarkan pie chart sebagai berikut.

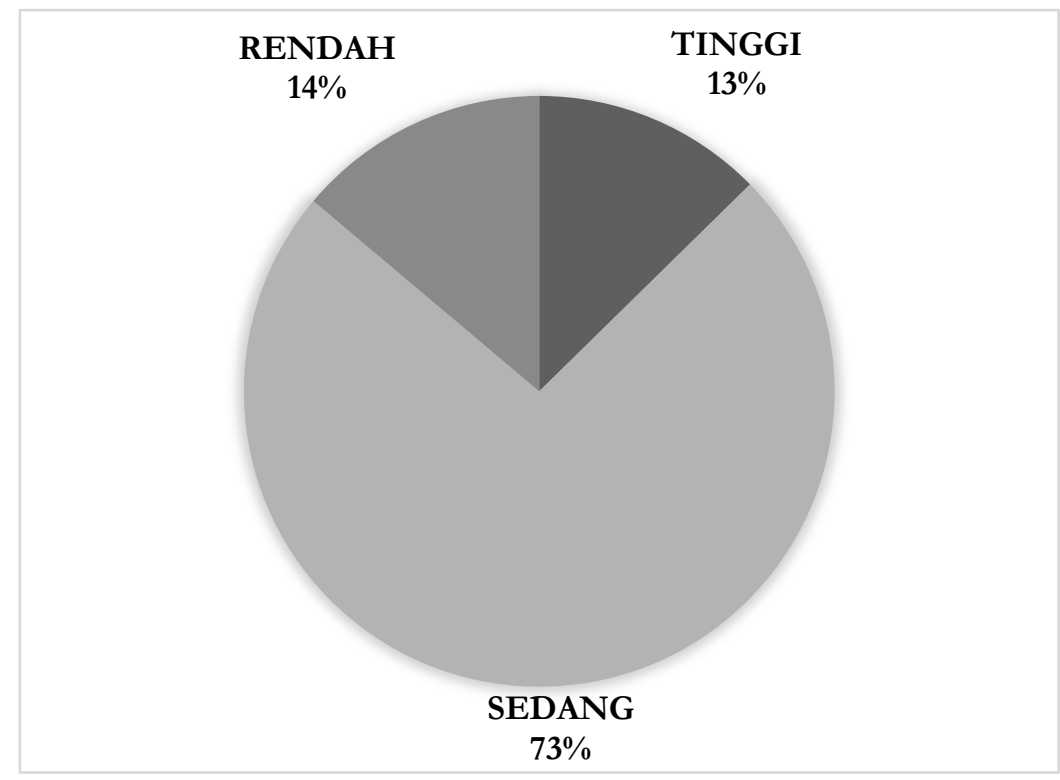

Gambar 2.

Distribusi Kecenderungan Variabel Kemampuan Menulis Teks Eksposisi

Pengujian hipotesis dilakukan untuk mengetahui apakah hipotesis yang diajukan berdasarkan kajian teoritis diterima atau ditolak. Hipotesis yang diuji dalam penelitian ini adalah adanya hubungan yang signifikan antara variabel bebas dan variabel terikat baik secara sendiri maupun secara bersama-sama. Hipotesis merupakan jawaban sementara atas permasalahan yang dirumuskan. Oleh karena itu jawaban sementara itu harus diuji kebenarannya secara empirik. Pengujian hipotesis ini dilakukan dengan menggunakan teknik korelasi product moment, Untuk membantu proses analisis dilakukan dengan bantuan komputer program SPSS versi 20.
3. Hubungan Minat Baca dan Kemampuan Menulis Teks Ekposisi Siswa Kelas XI SMK Negeri 9 Samarinda

Untuk mengetahui adanya hubungan yang signifikan antara minat baca dan kemampuan menulis eksposisi dirumuskan hipotesis sebagai berikut:

$\mathrm{H}_{0}$ : Tidak ada hubungan yang signifikan antara $\mathrm{X}$ dengan $\mathrm{Y}$

$\mathrm{H}_{1}$ : Ada hubungan yang signifikan antara $\mathrm{X}$ dengan $\mathrm{Y}$.

Berdasarkan hasil analisis dengan menggunakan koefisien korelasi Product Moment. Dari hasil pengolahan data kuesioner dengan menggunakan program SPSS 20 diperoleh hasil sebagai berikut. 
Tabel 5. Rekap Hasil Analisis Korelasi

\begin{tabular}{cccccc}
\hline Variabel & $\begin{array}{c}\text { Pearson } \\
\text { Coleration }\end{array}$ & $\mathbf{N}$ & $\mathbf{r}_{\text {tabel }}$ & $\mathbf{P}$ & Keterangan \\
\hline Minat Baca & 0,305 & 166 & 0,159 & 0,000 & $\begin{array}{c}\text { Hipotesis } \mathrm{H}_{1} \text { diterima dan } \\
\text { signifikan }\end{array}$ \\
\hline
\end{tabular}

Berdasarkan tabel 5 hasil pengujian untuk variabel minat baca dan kemampuan menulis teks ekposisi diperoleh koefisien korelasi sebesar 0,305. Hal ini menjelaskan keeratan hubungan antara minat baca dan kemampuan menulis teks ekposisi berhubungan positif dan termaksud dalam kategori rendah. Data hasil analisisi diatas juga menunjukkan bahwa nilai $\mathrm{r}$ hitung $(0,305)>\mathrm{r}$ tabel $(0,159)$ dan Signifikan $(0,000)<\alpha(0,05)$ maka $\mathrm{H} 0$ ditolak sehingga dapat disimpulakan bahwa ada hubungan yang signifikan antara minat baca dan kemampuan menulis teks ekposisi.

\section{Keterbatasan Penelitian}

Pelaksanaan penelitian ini telah dilaksanakan sebaik mungkin dengan prosedur dan ketentuan yang berlaku. Namun demikian terdapat beberapa keterbatasan yang tidak dapat dihindarkan dalam penelitian ini. Keterbatasan tersebut antara lain sebagai berikut.

Hasil dan simpulan yang diperoleh dari penelitian ini kemungkinan hanya berlaku pada siswa Sekolah Menengah Kejuruan Negeri 9 Samarinda pada kelas XI yang dijadikan subjek penelitian sehingga tidak dapat digeneralisasikan untuk subjek yang memiliki karateristik yang berbeda. Keterbatasan peneliti yang bukan merupakan guru kelas atau guru yang bisa langsung menerapkan atau mengaplikasiskan ilmu pengetahuan sehingga dalam penelitian ini memerlukan bimbingan dari teman sejawat yang berprofesi sebagai guru dalam membantu penelitian ini. Penelitian ini menggunakan instrumen angket dan tes. Pengisian angket yang dilakukan oleh siswa sedikit sulit dikontrol berkaitan dengan kondisi siswa dan kondisi lingkungan siswa. Suasana kelas yang kurang kondusif juga mempengaruhi dalam mengerjakan angket minat baca, tes penguasaan kebahasaan, dan menulis teks eksposisi. Siswa mungkin saja memberikan jawaban yang tidak sesuai dengan keadaan atau kondisi yang sebenarnya terjadi, sehingga memengaruhi analisis data, yang pada berpengaruh terhadap hasil penelitian ini. Meskipun sebelum mengisi angket sudah dijelaskan untuk mengisi dengan jujur dan sesuai dengan keadaan sebenarnya.

Keterbatasan tersebut dikemukakan sebagai bahan pertimbangan guna menormalisasikan penelitian bukan bertujuan sebagai pembelaan atau pembenaran pernyataan.

\section{E. PENUTUP}

Berdasarkan data yang diperoleh dan hasil pembahasaan dan analisis data yang dilakukan maka dapat diperoleh simpulan sebagai berikut. Hasil analisis korelasi sederhana menunjukkan bahwa hipotesis yang menyatakan "tampaknya ada korelasi yang signifikan antara minat baca dengan kemampuan menulis teks eksposisi siswa kelas XI SMK Negeri 9 Samarinda" telah teruji kebenarannya. Minat baca berhubungan positif dan signifikan terhadap kemampuan menulis teks eskposisi. Hubungan yang positif dan signifikan tersebut ditunjukkan dengan koefisien korelasi sebesar 0,305 dan nilai $r_{\text {hitung }}$ lebih besar dari nilai $r_{\text {tabel }}$ dengan $\mathrm{N}=166$ pada taraf kesalahan 5\% $(0,305>0,159)$. Hal ini menunjukkan bahwa terjadi hubungan antara minat baca dengan kemampuan menulis teks 
ekposisi. Sedangkan arah hubungan adalah positif karena nilai $r$ positif, berarti semakin tinggi minat baca maka semakin meningkatkan kemampuan menuis teks eksposisi siswa kelas XI SMK Negeri 9 Samarinda.

\section{DAFTAR PUSTAKA}

Aliponga, J. (2013). Reading Journal: Its Benefits for Extensive Reading. Internasional Journal of Humanities and Sosial Science, 3(12), 73-80. Diperoleh dari

http://www.ijhssnet.com/journal/in dex/1896

Arikunto. (1997). Dasar-Dasar Evaluasi Pendidikan. Jakarta: Bumi Aksara.

Arikunto, S. (2011). Dasar-Dasar Evaluasi Pendidikan. Jakarta: Bumi Aksara.

Arikunto, S. (2014). Prosedur Penelitian Suatu Pendekatan Praktik. Jakarta: Rineka Cipta.

Ghazali, A. S. (2010). Pembelajaran Keterampilan Berbahasa dengan Pendekatan Komunikatif-Interktif. Bandung: Refika Aditama

Iskandarwassid. (2009). Strategi Pembelajaran Bahasa. Bandung: Penerbit Rosda.

Jahja, Y. (2011). Psikologi Perkembangan. Jakarta: Prenada Media Group

Janah, N. M. (2014). Hubungan Minat Baca dan Pengusaan Kosakata dengan Kemampuan Menulis Teks Eksposisi pada Siswa Kelas X SMA Negeri Sekabupaten Bantul. Skripsi Universitas Negeri Yogyakarta.

Keraf, G. (2010). Diksi dan Gaya Bahasa. Jakarta: PT Gramedia Pustaka Utama.

Kosasih, E. (2017). Bahasa Indonesia/Kementrian Pendidikan dan Kebudayaan. Edisi Revisi. Jakarta: Balitbang.
Kridalaksana, H. (2008). Kamus Linguistike edisi Keempat. Jakarta: PT Gramedia Pustaka Utama.

Marbun, S. M. (2018). Psikologi Pendidikan. Ponorogo: Uwais Inspirasi Indonesia.

McCutchen, D. (2011). From Novice to Expert: Implications of Language Skills and Writing-Relevant Knowledge for Memory during the Development of Writing Skill. Journal of Writing Research, 3(1), 51-68. doi:10.17239/jowr-2011.03.01.3

Saddhono, K. \& Slamet, St. Y. (2012). Meningkatkan Keterampilan Berbahasa Indonesia: Teori dan Aplikasi. Bandung: Karya Putra Darwati.

Setyosari, P. (2010). Metode Penlitian Pendidikan \& Pengembangan. Jakarta: Prenadamedia Group.

Sugiyono. (2004). Metode Penelitian Kuantitatif, Kualitatif, dan Kombinasi (MixedMethods). Bandung: Alfabeta.

Sugiyono. (2007). Metode Penelitian Pendidikan. Bandung: Alfabeta.

Suparno \& Yunus, M. (2008). Keterampilan Dasar Menulis. Jakarta: Penerbit Universitas Terbuka.

Surakmad. (1994). Tuntunan Metodologi Belajar. Jakarta: Grasindo.

Tarigan, D. (2002). Pendidikan Keterampilan Berbahasa. Jakarta: Penerbit Universitas Terbuka.

Tarigan, H. G. (2008). Membaca: Sebagai Suatu Keterampilan Berbahasa. Bandung: Penerbit Angkasa.

Wahyuni, U. (2017). Kontribusi Minat Baca dan Penguasaan Kalimat Terhadap Keterampilan Menulis Teks Eksposisi. Pena: Jurnal Pendidikan Bahasa dan Sastra, 7(1), 100-114. Diperoleh dari https://online- 
journal.unja.ac.id/index.php/pena/a rticle/view/4371

Widiyarto, S. (2017). Pengaruh Minat Baca dan Penguasaan Kosa Kata terhadap Keterampilan Menulis Eksposisi. Pesona: Jurnal Kajian Bahasa dan Sastra Indonesia, 3(1), 74-80. Diperoleh dari http:/ / ejournal.stkipmpringsewulpg.ac.id/index.php/pesona/article/ view $/ 240$

Yuliatun. (2009). Hubungan Minat Membaca dan Penguasaan Kosakata dengan Keterampilan Berbicara Siswa Kelas Vi Sekolah Dasar Negeri 2 Bulusulur di Kecamatan Wonogiri Kabupaten Wonogiri. Disertasi. Universitas Sebelas Maret Surakarta.

Yusuf, A. (2017). Model Pembelajaran Inquiry dan Minat Membaca dalam Pembelajaran Menulis Cerita Pendek (Cerpen) Siswa Kelas X MIPA SMA Negeri 3 Samarinda. Tesis. Universitas Mulawarman, Samarinda. 